\title{
Use of Anions To Allow Translational Isomerism of a [2]Rotaxane
}

\author{
Chi-Feng Lin, ${ }^{[a]}$ Chien-Chen Lai, ${ }^{[b]}$ Yi-Hung Liu, ${ }^{[a]}$ Shie-Ming Peng, ${ }^{[a]}$ and \\ Sheng-Hsien Chiu*[a]
}

\begin{abstract}
We report a molecular [2]rotaxane which comprises a molecular cage and a dumbbell-shaped component, in which translational isomerism can be performed reversibly through an in situ anion exchange process, that is, sequential addition of $\mathrm{Bu}_{4} \mathrm{NCl} /$ $\mathrm{AgPF}_{6}$ reagent pairs. The [2] rotaxane
\end{abstract}

incorporates two pyridinium and two dialkylammonium centers and functions as a triply operable molecular

Keywords: anion switch • hostguest systems - molecular cages . molecular machines $\cdot$ rotaxanes switch, which can be controlled through altering the polarity of the solvent, adding acidic and basic reagents $\left(\mathrm{TFA} / \mathrm{Et}_{3} \mathrm{~N}\right)$, and the varying the nature of the counteranions $\left(\mathrm{Cl}^{-}\right.$vs $\mathrm{PF}_{6}{ }^{-}$).

\section{Introduction}

Although supramolecular systems that recognize cations and anions were discovered at about the same time, ${ }^{[1]}$ progress in anion binding occurred sporadically up to late 1980s possibly because of the larger sizes, diverse shapes, and higher solvation energies of anions relative to those of cations. ${ }^{[2]}$ Studies into anion recognition systems have, however, become popular since then, with many systems exhibiting features comparable to those of cation-based supramolecular species. ${ }^{[3]}$ Although cations have been utilized for quite some time to mediate the translational isomerization of interlocked molecules - that is, to switch machine-like systems between different states $^{[4]}$-reports of the application of anions to such tasks are rare. The addition of cations to machine-like molecules inevitably involves the simultaneous addition of anions; if such anions also induce specific molec-

[a] C.-F. Lin, Y.-H. Liu, Prof. S.-M. Peng, Prof. S.-H. Chiu Department of Chemistry

National Taiwan University

No. 1, Sec. 4, Roosevelt Road, Taipei (Taiwan, ROC)

Fax: (+886)2-3366-1677

E-mail:shchiu@ntu.edu.tw

[b] Prof. C.-C. Lai

Institute of Molecular Biology

National Chung Hsing University

and

Department of Medical Genetics, China Medical University Hospital Taichung (Taiwan, ROC)

Supporting information for this article is available on the WWW under http://www.chemeurj.org/ or from the author. ular motion within functional interlocked molecules, then the addition of a single salt could, in theory, be used to operate two separate events within a multifunctional molecular machine. To the best of our knowledge, the only reversible anion-controlled in situ translational isomerism was one reported by the Leigh group for a [2]rotaxane that operated through hydrogen bonding between the macrocyclic unit and a phenoxide motif on the thread-like component. ${ }^{[5]}$ Surprisingly, counteranion-induced in situ reversible translational isomerism of bistable [2] rotaxanes has not been described previously. ${ }^{[6]}$ In this paper, we report a molecular [2]rotaxane comprising a molecular cage and a dumbbell-shaped component; the latter incorporating two pyridinium and two dialkylammonium centers, in which translational isomerism can be performed reversibly through an in situ anion exchange process, that is, sequential addition of $\mathrm{Bu}_{4} \mathrm{NCl} /$ $\mathrm{AgPF}_{6}$ reagent pairs.

\section{Result and Discussion}

Previously, we demonstrated that the rod-shaped salt $2 \cdot 2 \mathrm{PF}_{6}$ can penetrate through the two 24 -membered rings of molecular cage 1 to form a complex stabilized through multiple $[\mathrm{C}-\mathrm{H}$... O ] hydrogen bonds between the $\alpha$-protons of the pyridinium centers of $\mathbf{2}^{2+}$ and the oxygen atoms of the ethylene glycol chains of 1 (Scheme 1). ${ }^{[7]}$ In order to prepare the corresponding [2]rotaxanes from such a system we used the threading-followed-by-stoppering approach. ${ }^{[8]}$ We synthesized a functionalized derivative, $3 \cdot 2 \mathrm{PF}_{6}$, by reacting $1,2-$ bis(4-pyridyl)ethane with 1,5-dibromopentane and expected 

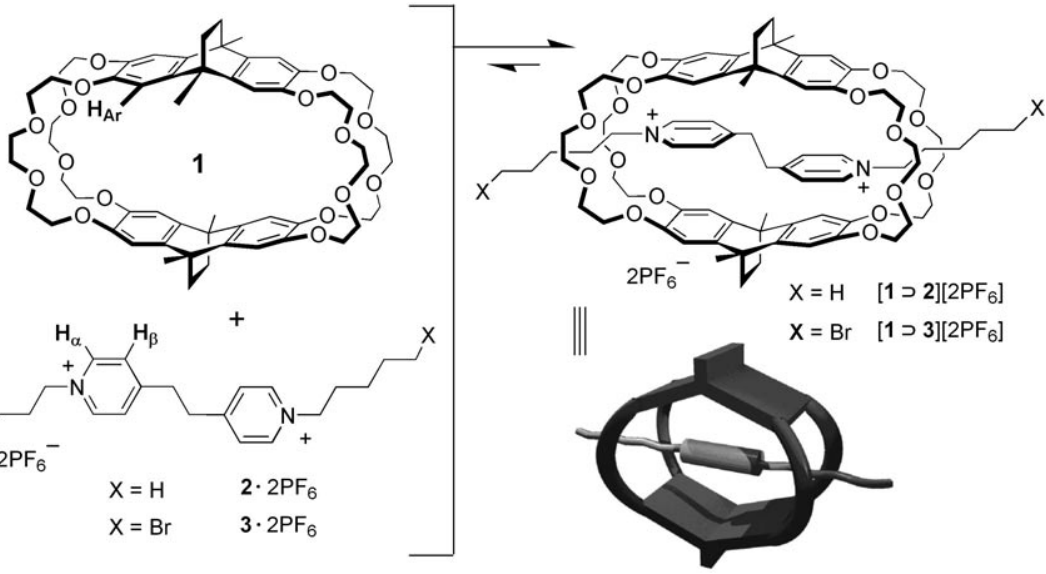

Scheme 1. Complexation of molecular cage $\mathbf{1}$ with the rod-like salts $2 \cdot 2 \mathrm{PF}_{6}$ and $\mathbf{3} \cdot 2 \mathrm{PF}_{6}$. macrocyclic unit in $\mathbf{5} \cdot 4 \mathrm{PF}_{6}$ resides predominately about this central unit in $\mathrm{CD}_{3} \mathrm{CN}$ at room temperature (Figure 1).

Single crystals suitable for X-ray crystallography were obtained by liquid diffusion of isopropyl ether into a $\mathrm{CH}_{3} \mathrm{CN}$ solution of $\mathbf{5} \cdot 4 \mathrm{PF}_{6}$. The solidstate structure ${ }^{[9]}$ (Figure 2) reveals the expected [2]rotaxane molecular geometry: the rodlike component is encircled by the two 24-membered-ring openings of molecular cage $\mathbf{1}$, which resides about the central bipyridinium moiety of the dumbbell-shaped component.

The ${ }^{1} \mathrm{H}$ NMR spectrum of [2] rotaxane $7-2 \mathrm{H} \cdot 4 \mathrm{PF}_{6}$ in $\mathrm{CD}_{3} \mathrm{NO}_{2}$ (Figure 1d) is relatively complex: it displays signals corresponding to a 1:4 mixture of the translational isomers $[7 \mathbf{a}-2 \mathrm{H}]^{4+}$ and $[\mathbf{7 b}-2 \mathrm{H}]^{4+}$ (Scheme 3 ). The ratio of these two translational isomers was solvent-dependent: In a polar solvent which would favor $\pi$-stacking over hydrogen-bonding interactions, such as $\mathrm{CD}_{3} \mathrm{CN}$, we observed exclusively the symmetrical translational isomer $[7 \mathbf{a}-2 \mathrm{H}]^{4+}$ (Figure 1c); because $\mathrm{CD}_{3} \mathrm{NO}_{2}$ is less disruptive of hydrogen bonds (relative to $\mathrm{CD}_{3} \mathrm{CN}$ ), its use as the solvent provided predominately the unsymmetrical translational isomer $[\mathbf{7 b}-2 \mathrm{H}]^{4+} \cdot{ }^{[10]}$ The addition of 2 equiv of triethylamine to [2]rotaxane 7$2 \mathrm{H} \cdot 4 \mathrm{PF}_{6}$ in $\mathrm{CD}_{3} \mathrm{NO}_{2}$ provided a ${ }^{1} \mathrm{H} \mathrm{NMR}$ spectrum (Figure $3 \mathrm{~b}$ ) similar to that of the [2] rotaxane $\mathbf{5 . 4} \mathrm{PF}_{6}$ in the same solvent (see the Supporting Information); this observation implies that the macrocyclic unit migrated to the central bipyridinium center in the [2] rotaxane $7 \cdot 2 \mathrm{PF}_{6}$ because of the we did not observe additional signals, it appears that the
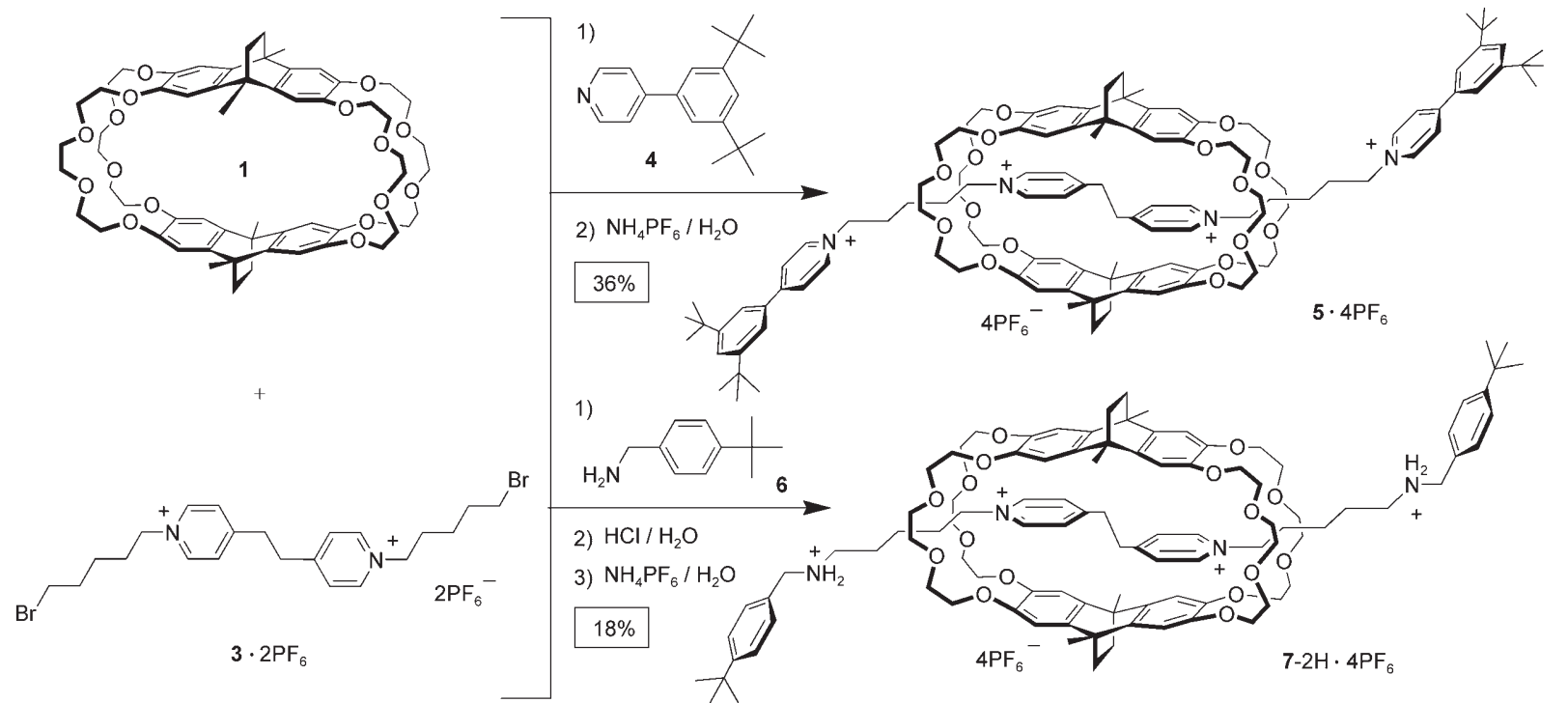

Scheme 2. Syntheses of molecular cage-based [2]rotaxanes. 


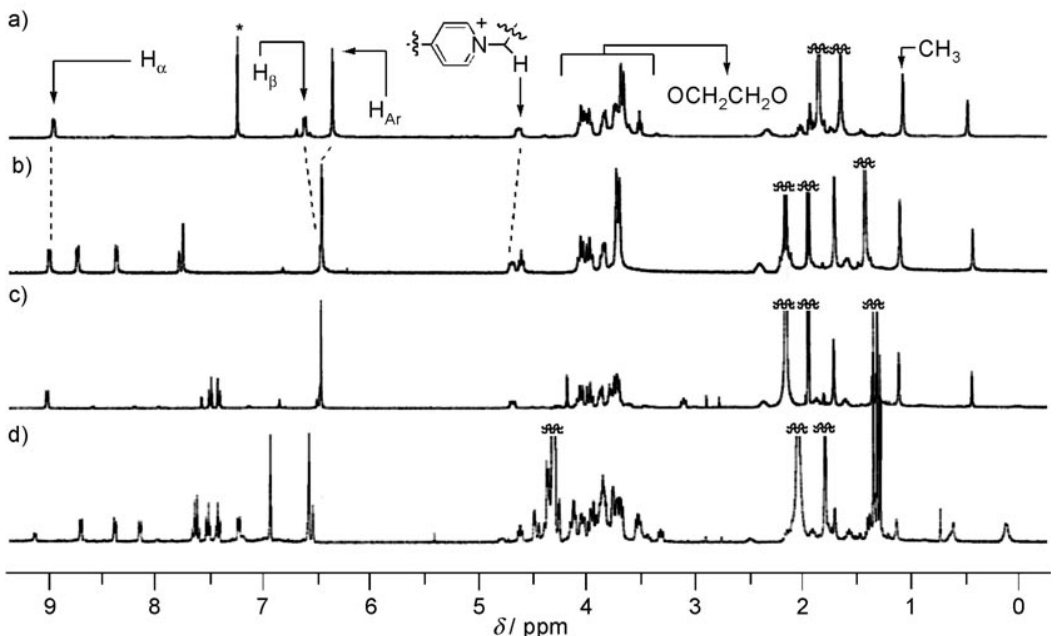

Figure 1. Partial ${ }^{1} \mathrm{H}$ NMR spectra $(400 \mathrm{MHz}, 298 \mathrm{~K})$ of a) equimolar mixture of $\mathbf{1}$ and $\mathbf{3} \cdot 2 \mathrm{PF}_{6}\left(3 \mathrm{~mm}, \mathrm{CD}_{3} \mathrm{CN} /\right.$ $\mathrm{CDCl}_{3} 9: 1$; b) [2]rotaxane $\mathbf{5} \cdot 4 \mathrm{PF}_{6}\left(\mathrm{CD}_{3} \mathrm{CN}\right)$; c) [2] rotaxane 7-2H.4 $\mathrm{PF}_{6}\left(\mathrm{CD}_{3} \mathrm{CN}\right)$; d) [2] rotaxane 7-2 $\mathrm{H} \cdot 4 \mathrm{PF}_{6}$ $\left(\mathrm{CD}_{3} \mathrm{NO}_{2}\right)$.

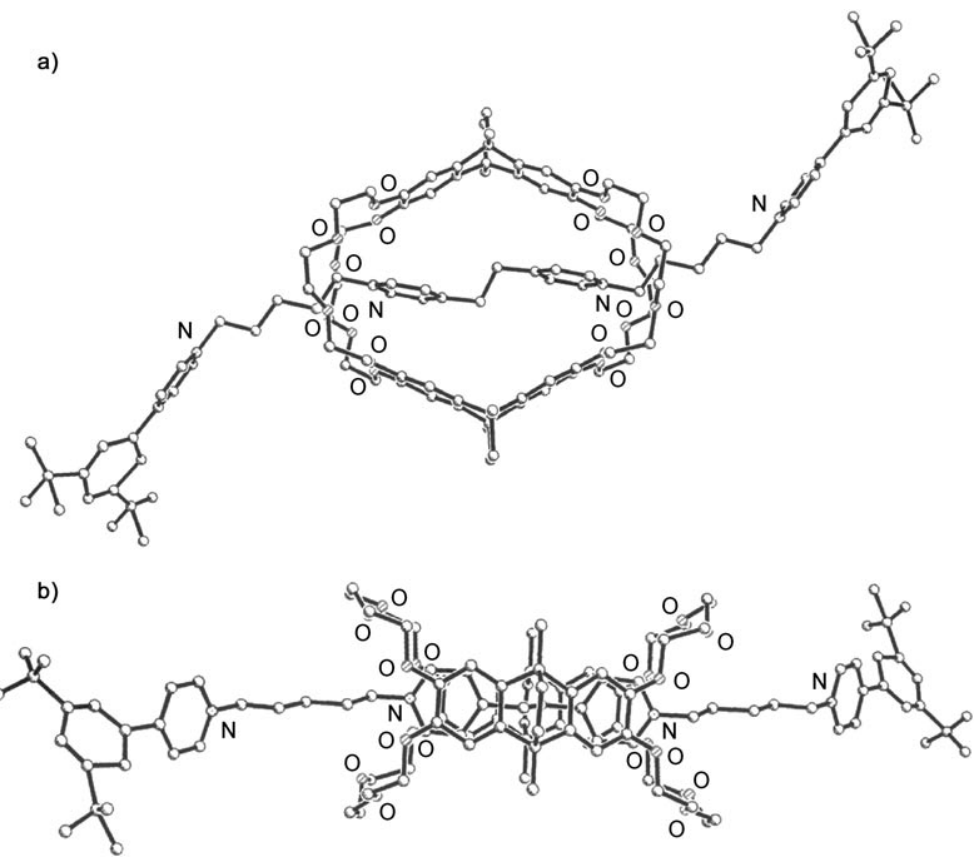

Figure 2. Ball-and-stick representation of the solid-state structure of rotaxane $\mathbf{5}^{4+}$.

weaker [N-H...O] hydrogen bonding that occurs after deprotonation of the terminal dialkylammonium units. Subsequent addition of 2 equiv of TFA to this solution resulted in a ${ }^{1} \mathrm{H}$ NMR spectrum (Figure 3c) similar to that of the original spectrum of [2] rotaxane $[7-2 \mathrm{H}]^{4+}$ (Figure 3a), but with the ratio of the two translational isomers deviating from 1:4, even after an excess of TFA had been added (Figure 3d).

We suspected that the change in the ratio of the two translational isomers in $\mathrm{CD}_{3} \mathrm{NO}_{2}$ after performing the acid/ base switching process was the result of the TFA anions, because the binding affinity of a crown ether to a dialkylammonium trifluoroacetate is weaker than that to the corre- sponding $\mathrm{PF}_{6}$ salt. ${ }^{[11]}$ Thus, we expected that if we were to introduce a counterion that binds tightly to dialkylammonium ions into the $\mathrm{CD}_{3} \mathrm{NO}_{2}$ solu-

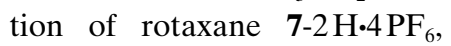
the crown ethers motifs of the molecular cage component would complex more poorly to the terminal $\mathrm{NH}_{2}{ }^{+}$units and, therefore, the translational isomer $[7 \mathbf{a}-2 \mathrm{H}]^{4+}$ would replace $[7 \mathbf{b}-2 \mathrm{H}]^{4+}$ as the predominant species in solution. Thus, after we had added 4 equiv of $\mathrm{Bu}_{4} \mathrm{NCl}$ to the $\mathrm{CD}_{3} \mathrm{NO}_{2}$ solution of 7$2 \mathrm{H} \cdot 4 \mathrm{PF}_{6}$, the originally complex ${ }^{1} \mathrm{H} N M R$ spectrum, in which the ratio of translational isomers $[\mathbf{7} \mathbf{a}-2 \mathrm{H}]^{4+}$ and $[\mathbf{7 b}-$ $2 \mathrm{H}]^{4+}$ was $1: 4$, simplified to a spectrum (Figure 4c) similar to the spectra of both the translational isomer $[7 \mathbf{a}-2 \mathrm{H}]^{4+}$ and the salt $5 \cdot 2 \mathrm{PF}_{6}$; this suggested that molecular cage $\mathbf{1}$ now resides about the central bipyridinium unit. Subsequent addition of 4 equiv of $\mathrm{AgPF}_{6}$-in order to remove the chloride anions from the solution-resulted in a spectrum (Figure $4 \mathrm{e}$ ) similar to that of the original $1: 4$ mixture of [7a$2 \mathrm{H}]^{4+}$ and $[7 \mathbf{b}-2 \mathrm{H}]^{4+}$; that is, the asymmetrical species $[\mathbf{7} \mathbf{b}$ $2 \mathrm{H}]^{4+}$ was regenerated as the predominant translational isomer in solution. ${ }^{[12]}$ Thus, the translational isomerization of 7-2 $\mathrm{H} \cdot 4 \mathrm{PF}_{6}$ in $\mathrm{CD}_{3} \mathrm{NO}_{2}$ can be operated in situ through exchange of this [2] rotaxane's counteranions. Indeed, this unique molecular switch can be controlled three ways: through changing the solvent polarity ${ }^{[13]}$ adding acidic/basic reagents, ${ }^{[8 \mathrm{c}, 14]}$ and switching the counteranions.

\section{Conclusion}

We have demonstrated that the strong binding affinity between the molecular cage $\mathbf{1}$ and the bipyridinium units of 3. $2 \mathrm{PF}_{6}$ allows the synthesis of the [2] rotaxane 7-2 $\mathrm{H} \cdot 4 \mathrm{PF}_{6}$ through a threading-followed-by-stoppering approach using 4-tert-butylbenzylamine as the nucleophile. The rotaxane 


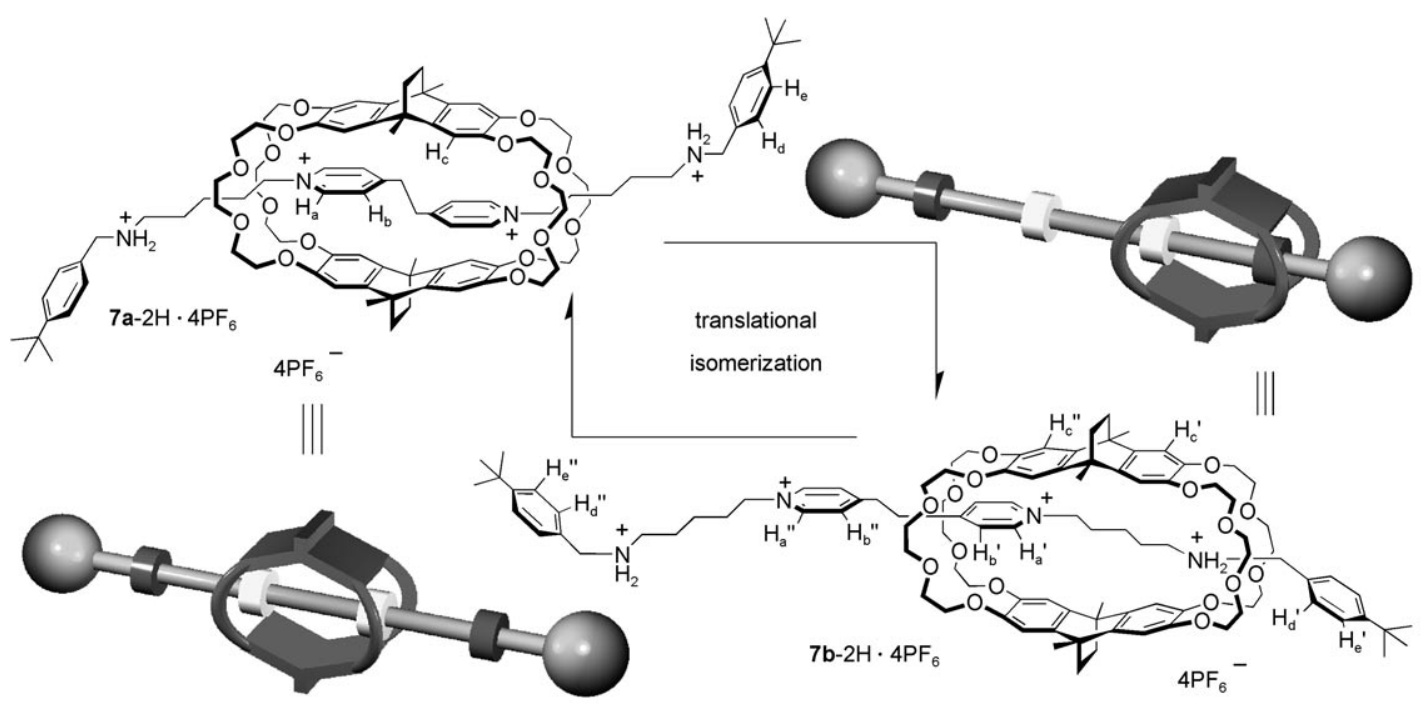

Scheme 3. Translational isomerization of rotaxane $7-2 \mathrm{H} \cdot 4 \mathrm{PF}_{6}$.
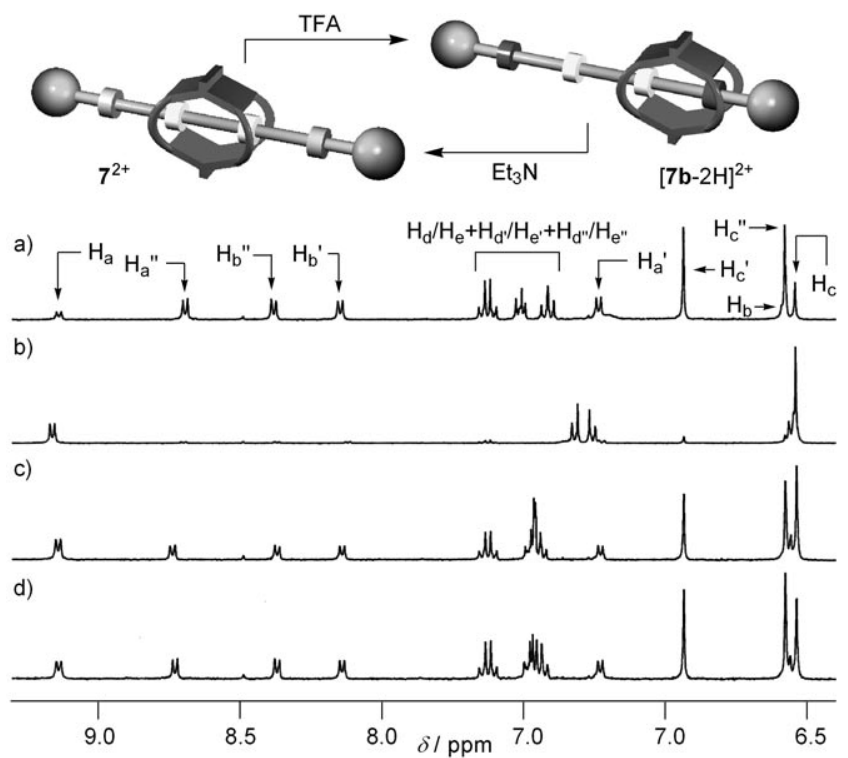

Figure 3. Partial ${ }^{1} \mathrm{H}$ NMR spectra $\left(400 \mathrm{MHz}, \mathrm{CD}_{3} \mathrm{NO}_{2}, 298 \mathrm{~K}\right)$ of a) rotaxane $7-2 \mathrm{H} \cdot 4 \mathrm{PF}_{6} ;$ b) reaction mixture obtained after adding $\mathrm{Et}_{3} \mathrm{~N}$ ( 2 equiv) to the solution in a); c) reaction mixture obtained after adding TFA (2 equiv) to the solution in $b$ ); d) reaction mixture obtained after adding TFA (1 equiv) to the solution in c).

exists as a $1: 4$ ratio of the translational isomers $[7 \mathbf{a}-2 \mathrm{H}]^{4+}$ and $[\mathbf{7 b}-2 \mathrm{H}]^{4+}$ in $\mathrm{CD}_{3} \mathrm{NO}_{2}$. This [2]rotaxane functions as a triply operable molecular switch, which can be controlled through altering the polarity of the solvent, adding acidic and basic reagents $\left(\mathrm{TFA} / \mathrm{Et}_{3} \mathrm{~N}\right)$, and the varying the nature of the counteranions $\left(\mathrm{Cl}^{-}\right.$vs $\left.\mathrm{PF}_{6}^{-}\right)$. To the best of our knowledge, this system represents the first example of counteranion-mediated switching of translational isomerism in situ; we believe that this result may be important in the design of multiple-input logic gates and molecular machines that exhibit efficient stepwise functions when operated through the addition of salts, that is, without modifying the covalent structure of the functional system.

\section{Experimental Section}

General: All glassware, stirrer bars, syringes, and needles were either oven- or flame-dried prior to use. All reagents, unless otherwise indicated, were obtained from commercial sources. Anhydrous $\mathrm{CH}_{2} \mathrm{Cl}_{2}$ and $\mathrm{CH}_{3} \mathrm{CN}$ were obtained by distillation from $\mathrm{CaH}_{2}$ under $\mathrm{N}_{2}$. Reactions were conducted under $\mathrm{N}_{2}$ or Ar. Thin-layer chromatography (TLC) was performed on Merck $0.25 \mathrm{~mm}$ silica gel (Merck No. 5715). Column chro-

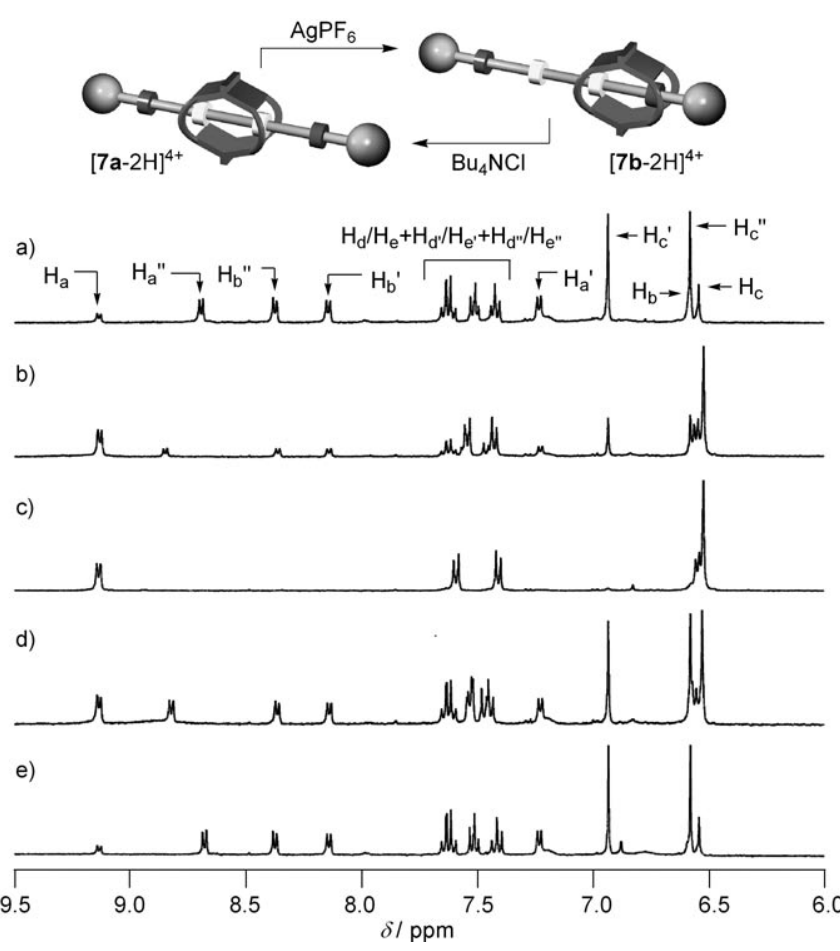

Figure 4. Partial ${ }^{1} \mathrm{H}$ NMR spectra $\left(400 \mathrm{MHz}, \mathrm{CD}_{3} \mathrm{NO}_{2}, 298 \mathrm{~K}\right)$ of a) rotaxane $7-2 \mathrm{H} \cdot 4 \mathrm{PF}_{6} ;$ b) reaction mixture obtained after adding $\mathrm{Bu}_{4} \mathrm{NCl}$ ( 2 equiv) to the solution in a); c) reaction mixture obtained after adding $\mathrm{Bu}_{4} \mathrm{NCl}(2$ equiv) to the solution in b); d) reaction mixture obtained after adding $\mathrm{AgPF}_{6}$ (2 equiv) to the solution in c); e) reaction mixture obtained after adding $\mathrm{AgPF}_{6}$ (2 equiv) to the solution in d). 
matography was undertaken over Kieselgel 60 (Merck, 70-230 mesh). Melting points are determined by Fargo MP-2D melting point apparatus. In NMR spectra, the deuterated solvent was used as the lock, while either the solvent's residual protons or TMS was employed as the internal standard. Chemical shifts are reported in parts per million (ppm). Mutiplicities are given as s (singlet), d (doublet), $\mathrm{t}$ (triplet), q (quartet), $\mathrm{m}$ (mutiplet), and br (broad).

X-ray crystallographic analysis: CCDC-615116 (5.4 $\left.\mathrm{PF}_{6}\right)$ contains the supplementary crystallographic data for this paper. These data can be obtained free of charge from The Cambridge Crystallographic Data Centre via www.ccdc.cam.ac.uk/data_request/cif.

Compound 3.2 PF 6 : A solution of 4,4'-ethylenedipyridine (300 mg, $1.63 \mathrm{mmol})$ and 1,5-dibromopentane $(2 \mathrm{~mL}, 14.6 \mathrm{mmol})$ in DMF $(9 \mathrm{~mL})$ was stirred at ambient temperature for $16 \mathrm{~h}$ before being poured into ethyl acetate $(15 \mathrm{~mL})$. The precipitate was filtered off and dissolved in $\mathrm{CH}_{3} \mathrm{CN}(10 \mathrm{~mL})$. Saturated aqueous $\mathrm{NH}_{4} \mathrm{PF}_{6}(10 \mathrm{~mL})$ was added and the organic solvent was evaporated under reduced pressure. The precipitate was collected and washed with $\mathrm{H}_{2} \mathrm{O}(20 \mathrm{~mL})$ to give $3 \cdot 2 \mathrm{PF}_{6}$ as a paleyellow solid (1.2 g, $95 \%$ ). M.p. $122-123{ }^{\circ} \mathrm{C} ;{ }^{1} \mathrm{H}$ NMR $\left(400 \mathrm{MHz}, \mathrm{CD}_{3} \mathrm{CN}\right)$ : $\delta=1.47$ (quint, $J=8 \mathrm{~Hz}, 4 \mathrm{H}), 1.83-2.02(\mathrm{~m}, 8 \mathrm{H}), 3.27(\mathrm{~s}, 4 \mathrm{H}), 3.48(\mathrm{t}, J=$ $7 \mathrm{~Hz}, 4 \mathrm{H}), 4.46(\mathrm{t}, J=7 \mathrm{~Hz}, 4 \mathrm{H}), 7.85(\mathrm{~d}, J=7 \mathrm{~Hz}, 4 \mathrm{H}), 8.54 \mathrm{ppm}(\mathrm{d}, J=$ $7 \mathrm{~Hz}, 4 \mathrm{H}) ;{ }^{13} \mathrm{C} \mathrm{NMR}\left(100 \mathrm{MHz}, \mathrm{CD}_{3} \mathrm{CN}\right): \delta=25.0,30.7,32.4,34.5,35.0$, 61.4, 128.3, 143.9, $160.3 \mathrm{ppm}$; HR-MS (ESI): $\mathrm{m} / \mathrm{z}$ : calcd for $\mathrm{C}_{22} \mathrm{H}_{32} \mathrm{Br}_{2} \mathrm{~F}_{6} \mathrm{~N}_{2} \mathrm{P}^{+}$: 627.0574; found: $627.0562\left[3 \cdot \mathrm{PF}_{6}\right]^{+}$.

Compound 4: 4-Pyridineboronic acid (1.28 g, $10.5 \mathrm{mmol}), \mathrm{MeOH}$ $(40 \mathrm{~mL})$, and $\mathrm{Na}_{2} \mathrm{CO}_{3}\left(2 \mathrm{M}\right.$ in $\left.\mathrm{H}_{2} \mathrm{O}, 40 \mathrm{~mL}\right)$ were added to a toluene $(56 \mathrm{~mL})$ solution of 1-bromo-3,5-di-tert-butylbenzene $(2 \mathrm{~g}, 7.43 \mathrm{mmol})$, tetrakis(triphenylphosphine)palladium $(0)(427 \mathrm{mg}, 0.37 \mathrm{mmol})$, and tritert-butylphosphine $(25 \mathrm{~mm}$ in toluene; $7.4 \mathrm{~mL}, 0.19 \mathrm{mmol}$ ) at room temperature. The solution was stirred at $90^{\circ} \mathrm{C}$ for $16 \mathrm{~h}$ before being partitioned between $\mathrm{CH}_{2} \mathrm{Cl}_{2}(500 \mathrm{~mL})$ and $\mathrm{H}_{2} \mathrm{O}(500 \mathrm{~mL})$. The organic layer was washed with $\mathrm{H}_{2} \mathrm{O}(200 \mathrm{~mL})$, dried $\left(\mathrm{MgSO}_{4}\right)$, and concentrated to give a crude product that was purified (silica gel; $\mathrm{MeOH} / \mathrm{CH}_{2} \mathrm{Cl}_{2}$ 1:99) to afford 4 as a pale-yellow solid $(1.7 \mathrm{~g}, 86 \%)$. M.p. $120-121{ }^{\circ} \mathrm{C} ;{ }^{1} \mathrm{H}$ NMR $\left(400 \mathrm{MHz}, \mathrm{CDCl}_{3}\right): \delta=1.37(\mathrm{~s}, 18 \mathrm{H}), 7.43(\mathrm{~s}, 2 \mathrm{H}), 7.46-7.52(\mathrm{~m}, 3 \mathrm{H})$, $8.63 \mathrm{ppm}(\mathrm{d}, J=5 \mathrm{~Hz}, 2 \mathrm{H}) ;{ }^{13} \mathrm{C}$ NMR $\left(100 \mathrm{MHz}, \mathrm{CDCl}_{3}\right): \delta=31.8,35.3$, 121.0, 121.7, 122.8, 137.2, 149.0, 149.5, $151.1 \mathrm{ppm}$; HR-MS (ESI): $\mathrm{m} / \mathrm{z}$ : calcd for $\mathrm{C}_{19} \mathrm{H}_{26} \mathrm{~N}$ : 268.2065 ; found: $268.2095[4+\mathrm{H}]^{+}$.

Compound 5.4 PF : Substituted pyridine 4 (33 mg, $0.12 \mathrm{mmol})$ was added at ambient temperature to a $\mathrm{CH}_{3} \mathrm{CN}(2 \mathrm{~mL})$ solution of dibromide 3. $2 \mathrm{PF}_{6}(37 \mathrm{mg}, 0.05 \mathrm{mmol})$ and $\mathbf{1}(50 \mathrm{mg}, 0.05 \mathrm{mmol})$. The mixture was then stirred at $80^{\circ} \mathrm{C}$ for $5 \mathrm{~d}$. The solution was cooled to room temperature and then $\mathrm{CH}_{3} \mathrm{CN}(10 \mathrm{~mL})$ and saturated aqueous $\mathrm{NH}_{4} \mathrm{PF}_{6}(10 \mathrm{~mL})$ were added. The organic solvent was evaporated under reduced pressure and the precipitate was collected, washed with $\mathrm{H}_{2} \mathrm{O}(20 \mathrm{~mL})$, and purified (silica gel; $\mathrm{MeOH} / \mathrm{CH}_{2} \mathrm{Cl}_{2}$ 5:95) to afford [2]rotaxane $5.4 \mathrm{PF}_{6}$ as a white solid (42 mg, 36\%). M.p. $>280{ }^{\circ} \mathrm{C}$ (decomp); ${ }^{1} \mathrm{H} \mathrm{NMR}(400 \mathrm{MHz}$, $\left.\mathrm{CD}_{3} \mathrm{CN}\right): \delta=0.41(\mathrm{~s}, 4 \mathrm{H}), 1.09(\mathrm{~s}, 8 \mathrm{H}), 1.41(\mathrm{~s}, 36 \mathrm{H}), 1.51-1.61(\mathrm{br}, 4 \mathrm{H})$, $1.69(\mathrm{~s}, 12 \mathrm{H}), 2.10-2.22(\mathrm{~m}, 4 \mathrm{H}), 2.31-2.41(\mathrm{br}, 4 \mathrm{H}), 3.65-4.10(\mathrm{~m}, 48 \mathrm{H})$, $4.60(\mathrm{t}, J=7 \mathrm{~Hz}, 4 \mathrm{H}), 4.67-4.72(\mathrm{~m}, 4 \mathrm{H}), 6.43-6.50(\mathrm{~m}, 12 \mathrm{H}), 7.74(\mathrm{~s}$, $4 \mathrm{H}), 7.78(\mathrm{~s}, 2 \mathrm{H}), 8.36(\mathrm{~d}, J=7 \mathrm{~Hz}, 4 \mathrm{H}), 8.72(\mathrm{~d}, J=7 \mathrm{~Hz}, 4 \mathrm{H}), 9.00 \mathrm{ppm}$ $(\mathrm{d}, J=7 \mathrm{~Hz}, 4 \mathrm{H}) ;{ }^{13} \mathrm{C}$ NMR $\left(100 \mathrm{MHz}, \mathrm{CD}_{3} \mathrm{CN}\right): \delta=18.4,24.4,28.6,31.3$, $31.9,35.7,36.5,37.5,41.7,59.9,61.7,68.5,70.4,70.9,105.2,122.6,122.7$, 125.5, 127.0, 133.6, 138.0, 144.1, 144.4, 146.1, 152.7, 157.0, 157.2 ppm; HRMS (ESI): $m / z$ : calcd for $\mathrm{C}_{120} \mathrm{H}_{158} \mathrm{~F}_{12} \mathrm{~N}_{4} \mathrm{O}_{16} \mathrm{P}_{2}^{2+}$ : 1100.5479; found: $1100.5556\left[\mathbf{5} \cdot 2 \mathrm{PF}_{6}\right]^{2+}$.

Compound 7-2 H.4 $\mathbf{P F}_{\mathbf{6}}$ : 4-tert-Butylbenzylamine $(18 \mu \mathrm{L}, 0.10 \mathrm{mmol})$ in $\mathrm{CH}_{3} \mathrm{CN} / \mathrm{CH}_{2} \mathrm{Cl}_{2}$ 3:1 (2 mL) was added dibromide $3 \cdot 2 \mathrm{PF}_{6} \quad(37 \mathrm{mg}$, $0.05 \mathrm{mmol}$ ) and $1(50 \mathrm{mg}, 0.05 \mathrm{mmol})$. The mixture was stirred at ambient temperature for $7 \mathrm{~d}$. The mixture was poured into a mixture of $\mathrm{HCl}(1 \mathrm{~N}$, $0.5 \mathrm{~mL})$ and $\mathrm{CH}_{3} \mathrm{CN}(10 \mathrm{~mL})$, saturated aqueous $\mathrm{NH}_{4} \mathrm{PF}_{6}(10 \mathrm{~mL})$ was added, and then the organic solvent was evaporated under reduced pressure. The precipitate was collected, washed with $\mathrm{H}_{2} \mathrm{O}(20 \mathrm{~mL})$, and then purified (silica gel; $\mathrm{MeOH} / \mathrm{CH}_{2} \mathrm{Cl}_{2} 5: 95$ ) to afford rotaxane $7-2 \mathrm{H} \cdot 4 \mathrm{PF}_{6}$ as a white solid $(20 \mathrm{mg}, 18 \%)$. M.p. $>262{ }^{\circ} \mathrm{C}$ (decomp); ${ }^{1} \mathrm{H}$ NMR $\left(400 \mathrm{MHz}, \mathrm{CD}_{3} \mathrm{COCD}_{3}\right): \delta=0.67(\mathrm{~s}, 4 \mathrm{H}), 1.11(\mathrm{~s}, 8 \mathrm{H}), 1.29(\mathrm{~s}, 18 \mathrm{H}), 1.73$ $(\mathrm{s}, 12 \mathrm{H}), 1.75-1.85(\mathrm{~m}, 4 \mathrm{H}), 2.18-2.24(\mathrm{~m}, 4 \mathrm{H}), 2.51-2.58(\mathrm{~m}, 4 \mathrm{H}), 3.57$ $(\mathrm{t}, J=7 \mathrm{~Hz}, 4 \mathrm{H}), 3.73-4.22(\mathrm{~m}, 48 \mathrm{H}), 4.56(\mathrm{~s}, 4 \mathrm{H}), 4.83(\mathrm{t}, J=7 \mathrm{~Hz}, 4 \mathrm{H})$, $6.57(\mathrm{~s}, 8 \mathrm{H}), 6.76(\mathrm{~d}, J=7 \mathrm{~Hz}, 4 \mathrm{H}), 7.48-7.55(\mathrm{~m}, 8 \mathrm{H}), 9.15 \mathrm{ppm}(\mathrm{d}, J=$ $7 \mathrm{~Hz}, 4 \mathrm{H}) ;{ }^{13} \mathrm{C} \mathrm{NMR}\left(100 \mathrm{MHz}, \mathrm{CD}_{3} \mathrm{CN}\right): \delta=18.5,25.0,26.9,28.8,31.5$, $35.5,36.8,37.8,42.1,48.8,52.2,60.4,69.2,71.0,71.5,106.1,123.7,127.1$, 129.0, 131.0, 139.1, 145.6, 147.3, 153.9, $158.2 \mathrm{ppm}$; HR-MS (ESI): $\mathrm{m} / z$ : calcd for $\mathrm{C}_{104} \mathrm{H}_{142} \mathrm{~F}_{12} \mathrm{~N}_{4} \mathrm{O}_{16} \mathrm{P}_{2}{ }^{2+}$ : 996.4852 ; found: $996.4873\left[7-2 \mathrm{H} \cdot 2 \mathrm{PF}_{6}\right]^{2+}$

\section{Acknowledgement}

This study was supported by the National Science Council, Taiwan (NSC95-2113-M-002-016-MY3).

[1] a) C. J. Pedersen, J. Am. Chem. Soc. 1967, 89, 7017-7036; b) H. E. Simmonds, C. H. Park, J. Am. Chem. Soc. 1968, 90, 2431-2432.

[2] a) F. P. Schmidtchen, M. Berger, Chem. Rev. 1997, 97, 1609-1646; b) J. W. Steed, J. L. Atwood, Supramolecular Chemistry, Wiley, New York, 2000.

[3] a) P. D. Beer, Acc. Chem. Res. 1998, 31, 71-80; b) T. S. Snowden, E. V. Anslyn, Curr. Opin. Chem. Biol. 1999, 3, 740-746; c) P. D. Beer, P. A. Gale, Angew. Chem. 2001, 113, 502-532; Angew. Chem. Int. Ed. 2001, 40, 486-516; d) J. L. Sessler, S. Camiolo, P. A. Gale, Coord. Chem. Rev. 2003, 240, 17-55; e) M. W. Hosseini, Coord. Chem. Rev. 2003, 240, 157-166; f) P. D. Beer, E. J. Hayes, Coord. Chem. Rev. 2003, 240, 167-189; g) J. M. Llinares, D. Powell, K. Bowman-James, Coord. Chem. Rev. 2003, 240, 57-75; h) R. Martinez-Manez, F. Sancenon, Chem. Rev. 2003, 103, 4419-4476; i) J. Yoon, S. K. Kim, N. J. Singh, K. S. Kim, Chem. Soc. Rev. 2006, 35, $355-360$; j) V. Amendola, D. Esteban-Gómez, L. Fabbrizzi, M. Licchelli, Acc. Chem. Res. 2006, 39, 343-353; k) P. A. Gale, Acc. Chem. Res. 2006, 39, 465-475.

[4] a) J.-P. Collin, C. Dietrich-Buchecker, P. Gavina, M. C. JimenezMolero, J.-P. Sauvage, Acc. Chem. Res. 2001, 34, 477-487; b) G. Kaiser, T. Jarrosson, S. Otto, Y.-F. Ng, A. D. Bond, J. K. M. Sanders, Angew. Chem. 2004, 116, 1993-1996; Angew. Chem. Int. Ed. 2004, 43, 1959-1962; c) T. Iijima, S. A. Vignon, H.-R. Tseng, T. Jarrosson, J. K. M. Sanders, F. Marchioni, M. Venturi, E. Apostoli, V. Balzani, J. F. Stoddart, Chem. Eur. J. 2004, 10, 6375-6392; d) J. D. Badjic', V. Balzani, A. Credi, S. Silvi, J. F. Stoddart, Science 2004, 303, 1845 1849.

[5] C. M. Keaveney, D. A. Leigh, Angew. Chem. 2004, 116, 1242-1244; Angew. Chem. Int. Ed. 2004, 43, 1222-1224.

[6] The only reported example of counterion-induced translational isomerism of which we are aware involves a bistable donor-acceptor [2]rotaxane that may require a separation funnel-based ion exchange process to restore at least one of the original states; see: B. W. Laursen, S. Nygaard, J. O. Jeppesen, J. F. Stoddart, Org. Lett. 2004, 6, 4167-4170.

[7] C.-F. Lin, Y.-H. Liu, C.-C. Lai, S.-M. Peng, S.-H. Chiu, Angew. Chem. 2006, 118, 3248-3253; Angew. Chem. Int. Ed. 2006, 45, 31763181.

[8] For recent examples, see: a) A. B. Braunschweig, C. M. Ronconi, J.Y. Han, F. Arico, S. J. Cantrill, J. F. Stoddart, S. I. Khan, A. J. P White, D. J. Williams, Eur. J. Org. Chem. 2006, 1857-1866; b) P. Mobian, J.-P. Collin, J.-P. Sauvage, Tetrahedron Lett. 2006, 47, 49074909 ; c) K.-W. Cheng, C.-C. Lai, P.-T. Chiang, S.-H. Chiu, Chem. Commun. 2006, 2854-2856.

[9] Crystal data for 5.4 $\mathrm{PF}_{6}:\left[\mathrm{C}_{120} \mathrm{H}_{158} \mathrm{O}_{16} \mathrm{~N}_{4}\right]\left[\mathrm{PF}_{6}\right]_{4}, M_{\mathrm{r}}=2492.38$, monoclinic, space group $P 2_{1} / n, a=21.3408(13), b=16.8593$ (9), $c=21.2143$ (11) $\AA, V=7019.4$ (7) $\AA^{3}, \rho_{\text {calcd }}=1.179 \mathrm{~g} \mathrm{~cm}^{-3}, \mu\left(\mathrm{Mo}_{\mathrm{K} \alpha}\right)=0.141 \mathrm{~mm}^{-1}$, $T=295$ (2) K, colorless needles; 12357 independent measured reflections, $F^{2}$ refinement, $R_{1}=0.1839, w R_{2}=0.3848$.

[10] The association constants $\left(K_{\mathrm{a}}\right)$ between dibenzo[24]crown-8 (DB24C8) and dibenzylammonium $\left(\mathrm{DBA}^{+}\right)$ion in $\mathrm{CD}_{3} \mathrm{CN}$ and $\mathrm{CD}_{3} \mathrm{NO}_{2}$ are reported to be 420 and $8000 \mathrm{M}^{-1}$, respectively; see: a) P. R. Ashton, P. J. Campbell, E. J. T. Chrystal, P. T. Glink, S. Menzer, D. Philp, N. Spencer, J. F. Stoddart, P. A. Tasker, D. J. Wil- 
liams, Angew. Chem. 1995, 107, 1997-2001; Angew. Chem. Int. Ed. Engl. 1995, 34, 1865-1868; b) S.-H. Chiu, K.-S. Liao, J.-K. Su, Tetrahedron Lett. 2004, 45, 213-216; for the influence of solvent on noncovalent interactions, see: c) C. A. Hunter, Angew. Chem. 2004, 116 , 5424-5439; Angew. Chem. Int. Ed. 2004, 43, 5310-5324.

[11] J. W. Jones, H. W. Gibson, J. Am. Chem. Soc. 2003, 125, 7001-7004.

[12] It has been shown that subsequent remove and addition chloride ions can control the threading and unthreading of a pseudorotaxane formed between (9-anthrylmethyl)methylammonium hexafluorophosphate and dibenzo[24]crown-8, see: M. Montalti, L. Prodi, Chem. Commun. 1998, 1461-1462.

[13] For examples of solvent-controlled translational isomerism of [2]rotaxanes, see: a) A. S. Lane, D. A. Leigh, A. Murphy, J. Am. Chem. Soc. 1997, 119, 11092-11093; b) T. Da Ros, D. M. Guldi, A. Farran Morales, D. A. Leigh, M. Prato, R. Turco, Org. Lett. 2003, 5, 689691; c) D. A. Leigh, M. A. F. Morales, E. M. Perez, J. K. Y. Wong,
C. G. Saiz, A. M. Z. Slawin, A. J. Carmichael, D. M. Haddleton, A. M. Brouwer, W. J. Buma, G. W. H. Wurpel, S. Leon, F. Zerbetto, Angew. Chem. 2005, 117, 3122-3127; Angew. Chem. Int. Ed. 2005, 44, $3062-3067$; d) S. J. Loeb, J. Tiburcio, S. J. Vella, Chem. Commun. 2006, $1598-1600$.

[14] For examples of acid/base-controllable molecular switches, see: a) A. M. Elizarov, S.-H. Chiu, J. F. Stoddart, J. Org. Chem. 2002, 67, 9175-9181; b) J. W. Lee, K. Kim, K. Kim, Chem. Commun. 2001, 1042-1043; c) J. W. Jones, W. S. Bryant, A. W. Bosman, R. A. J. Janssen, E. W. Meijer, H. W. Gibson, J. Org. Chem. 2003, 68, 2385 2389; d) F. Huang, K. A. Switek, H. W. Gibson, Chem. Commun. 2005, 3655-3657; e) M.-L. Yen, W.-S. Li, C.-C. Lai, I. Chao, S.-H. Chiu, Org. Lett. 2006, 8, 3223-3226.

Received: October 7, 2006 Revised: November 13, 2006 Published online: February 26, 2007 